\section{NOCTURNAL FEEDING BY THE TICKELL'S BLUE FLYCATCHER CYORNIS TICKELLIAE}

\section{Satish Kumar Sharma}

Foundation for Ecological Security, 18 - New Ahinsapuri, Fatehpura, Udaipur, Rajasthan 313001, India

Email: ${ }^{1}$ fesudaipur@hotmail.com

One the evening of 2 January 2005, I was searching for a colony of Indian Flying Fox (Pteropus giganteus) near Madareshwar Mahadeo temple, on the eastern outskirts of Banswara city in southern Rajasthan. Though I searched a big area I could not spot the roost. To get some clue about the roosting site of bats, I went to Madareshwar Mahadeo Temple to contact the priest. It was around $1800 \mathrm{hr}$ and it was getting dark. On the way I saw a Block Drongo (Dicrurus macrocerus) feeding on flying insects around an electric bulb at the Lord Ayyappa temple. I observed the Black Drongo for a few minutes and left the site, as I was much interested in flying foxes.

Madareswar Mahadeo temple is very near the Ayyappa temple. When I entered the temple campus, I saw two Black Drongos and two White-bellied Drongos (D. caerulescens) near a mercury bulb feeding on flying insects. The Black Drongos were continuously chasing the White-bellied Drongos. I stood a few meters away from the lamppost to observe their behaviour. I remained there for 10 minutes. The drongos continued their feeding without any hesitation; perhaps they were used to human beings.

When I walked further ahead, I found a male Tickell's Blue Flycatcher (Cyornis tickelliae) feeding on flying insects near another electic bulb below a dense crown and huge Ficus benghalensis tree near the staircase of the main temple. I sat down on the staircase to observe the flycatcher but it was disturbed and left the site and joined the drongo party near the mercury bulb. From a 20-m distance, I observed them for the next 15 minutes. They indulged in feeding without taking any notice. After meeting with the priest, I left the temple around $1900 \mathrm{hr}$ until when all three species were still busy feeding on insects.

Nocturnal feeding by Black Drongo inside human habitations, have been reported by Khan (1990), Nameer (1990) and Sharma (1991); and feeding by White-bellied Drongo by Sharma (2003). Drongos, especially the Black Drongo is considered very bold but nocturnal feeding by a shy bird like Tickell's Blue Flycatcher at a public place is quite strange. There is no scientific record of nocturnal feeding for Tickell's Blue Flycatcher available in literature. Perhaps the attraction of huge populations of flying insects towards electric lights of human habitations have decreased food options for forest dwelling birds, thereby encouraging insectivores birds to human settlements to have better feeding opportunities (Sharma, 2003).

(C) Zoo Outreach Organisation; www.zoosprint.org Manuscript 1359; Received 14 May 2005; Finally accepted 26 November 2005;

\section{REFERENCES}

Khan, A.R. (1990). Feeding habits of Black Drongo. Newsletter for Birdwatchers 30 (10\&11): 11

Nameer, P.O. (1990): Midnight feeding by Black Drongo. Newsletter for Birdwatchers 30(7\&8)

Sharma, S.K. (1991). Nocturnal feeding by Black Drongo. Newsletter for Birdwatchers 31(3\&4A): 8.

Sharma, S.K. (2003). Nocturnal feeding by White-bellied Drongo Dicrurus caerulescens. Journal of the Bombay Natural History Society 100(1): 144

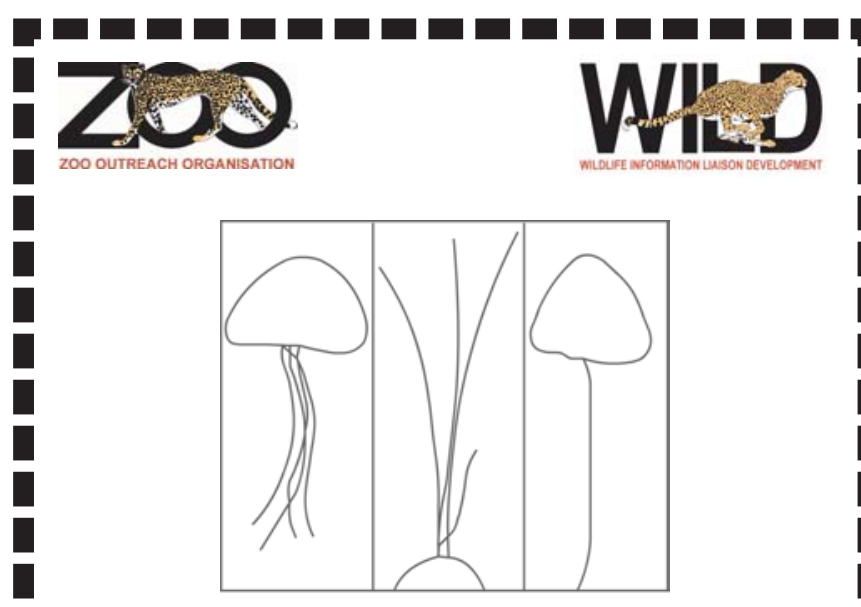

Threatened Taxa Monitoring System for south asian fauna, flora and fungi

launched!

Visit

www. southasiantaxa.org

for more information.

The website will be put up in three phases. The first part of First Phase is uploaded with most current taxonomic and conservation information

on selected groups of fauna and flora.

If you are interested in helping with this website, please write to us at

\title{
TTMS
}

c/o ZOO, WILD, CBSG South Asia

29-1 Bharathi Colony

Peelamedu, Coimbatore

Tamil Nadu 641004, India

zoocrew@vsnl.net,enquiry@southasiantaxa.org 